\title{
Urbanization and Slum Formation
}

\author{
Giok Ling Ooi and Kai Hong Phua
}

\begin{abstract}
The formation of slums need not be inevitable with rapid urbanization. Such an argument appears to be contradicted by evidence of large slum populations in a large number of developing countries and particularly in rapidly urbanizing regions like Asia. The evidence discussed suggests that city authorities faced with rapid urban development lack the capacity to cope with the diverse demands for infrastructural provision to meet economic and social needs. Not only are strategic planning and intervention major issues in agenda to manage rapid urbanization, but city governments are not effectively linking the economic development trajectory to implications for urban growth and, hence, housing needs. In the following discussion, a case study is presented in support of the argument that city governments have to first recognize and then act to establish the link that is crucial between economic development, urban growth, and housing. This is the agendum that has been largely neglected by city and national governments that have been narrowly focused on economic growth with the consequent proliferation of slum formation as a housing solution.
\end{abstract}

KEYWORDS Housing needs, Slum formation, Urbanization, Urban growth.

\section{UNDERSTANDING URBANIZATION AND URBAN GROWTH IN THE DEVELOPING WORLD}

The understanding of the level of urbanization or its scale in developing countries is challenged by differences in the definition of "urban" and in turn, the lack of reliable data. Furthermore, the process of urbanization is far from homogenous across regions and swathes of territory that are wholly different in terms of economy and political structures. In many of the poorest countries, there are cities that are really urban or metropolitan regions in terms of population sizes and territorial extent.

Where local governments are in place, they invariably lack the financial and expert capacity to carry out the work needed to address urban problems. Similar constraints are faced by numerous nongovernment organizations, which work at the local scale among poor neighborhoods in cities. Consequently, there is a problem of representation of the local needs in particularly poor urban neighborhoods and it can be assumed that areas like the squatter and slum settlements often have little or no legal claims on city or national governments.

Cities have become centers where vast numbers of people compete for the most basic elements of life: for a room within reach of employment with an affordable rent, or vacant land on which a shelter can be erected without fear of eviction;

Ooi is with the National Institute of Education, Nanyang Technological University, Singapore, Singapore; Phua is with National University of Singapore, Singapore, Singapore.

Correspondence: Giok Ling Ooi, National Institute of Education, Nanyang Technological University, Singapore, Singapore. (E-mail: giokling.ooi@nie.edu.sg) 
for places in schools; for medical treatment for health problems or injuries, or a bed in a hospital; for access to clean drinking water; for a place on a bus or train; and for a corner on a pavement or square to sell some goods-quite apart from the enormous competition for jobs. In the majority of cases, governments have the power and resources to increase the supply and reduce the cost of many of these. ${ }^{1}$

That urban slums and squatter settlements are not inevitable is evident in cities such as Hong Kong and Singapore. The following discussion focuses on the effective link established between planned economic development, urban growth, and housing, which has addressed slum formation in these cities.

\section{URBANIZATION AND ECONOMIC DEVELOPMENT IN THE DEVELOPING WORLD}

The urban population in the world is rising generally. ${ }^{2}$ The estimates are that more than $60 \%$ of the increase in the world's urban population over the next three decades will be in Asia, mostly in China and India, but also in Pakistan, Bangladesh, the Philippines, and Vietnam. Nine out of 23 cities with populations of more than 10 million people are in Asia. Similarly, Asia will have many cities projected to have more than a million people each. In Table 1, the urban growth rates in most parts of Asia are more rapid than that of the world. Concomitantly, the rate of decrease in the rural population in Asia as a whole and a number of subregions is projected to be higher than that of the world.

Whereas urbanization, defined in terms of population growth in urban areas, has been driven by economic development, poverty is also urbanizing. This is reflected in poor housing, urban infrastructural support, and social and reproductive health services. The per capita GDP figures illustrated in Table 2 are higher in the relatively more urbanized and developed countries including South Korea and Japan. Per capita GDP figures are double or triple those in other developing Asian countries, which are also less urbanized (see Table 2). This reflects the drawing power of cities for rural migrants seeking more economic opportunities.

Indeed, the GDP per capita figures in most cities in Asian developing countries are higher than their national incomes (see Table 3). Effort to slow down or redirect

TABLE 1 Urban and rural population growth rates, 1950-2030

\begin{tabular}{|c|c|c|c|c|c|c|c|c|}
\hline & \multicolumn{4}{|c|}{ Urban population (\%) } & \multicolumn{4}{|c|}{ Average annual rate of change (\%) } \\
\hline & \multirow[b]{2}{*}{1950} & \multirow[b]{2}{*}{1975} & \multirow[b]{2}{*}{2000} & \multirow[b]{2}{*}{2025} & \multicolumn{2}{|c|}{ Urban } & \multicolumn{2}{|c|}{ Rural } \\
\hline & & & & & $\begin{array}{l}2000- \\
2005\end{array}$ & $\begin{array}{l}2025- \\
2030\end{array}$ & $\begin{array}{l}2000- \\
2005\end{array}$ & $\begin{array}{l}2025- \\
2030\end{array}$ \\
\hline Asia & 17.4 & 24.7 & 36.7 & 50.6 & 1.31 & 1.10 & -0.80 & -1.19 \\
\hline Eastern Asia & 18.0 & 25.2 & 38.5 & 51.8 & 1.20 & 1.06 & -0.79 & -1.20 \\
\hline South Central Asia & 16.6 & 22.2 & 30.6 & 44.7 & 1.36 & 1.37 & -0.63 & -1.18 \\
\hline South Eastern Asia & 14.8 & 22.3 & 37.2 & 53.2 & 1.85 & 1.00 & -1.18 & -1.20 \\
\hline Western Asia & 26.7 & 48.5 & 70.2 & 77.0 & 0.71 & 0.26 & -1.77 & -0.97 \\
\hline World total & 29.7 & 37.9 & 47.0 & 58.0 & 0.83 & 0.77 & -0.86 & -1.12 \\
\hline
\end{tabular}

Source: United Nations (2000) pp. 28-31, 72-73, 76-77 
TABLE 2 Urbanization and national GDP

\begin{tabular}{|c|c|c|}
\hline & National GDP per capita, 2004 (US\$) & Urban population, 2000 (\%) \\
\hline Japan & 29,251 & 78.8 \\
\hline Singapore & 28,077 & 100.0 \\
\hline Korea, Democratic Republic & 20,499 & 81.9 \\
\hline Thailand & 8,090 & 21.6 \\
\hline Philippines & 4,614 & 58.6 \\
\hline Indonesia & 3,690 & 40.9 \\
\hline China & 5,896 & 32.1 \\
\hline
\end{tabular}

Sources: World Bank (2006) World Development Indicators 2006. Washington, DC (CD-ROM); United Nations (2000)

migration from the largest cities to the smaller urban areas has only led to the further expansion of these cities in the developing world. ${ }^{3}$

The Philippines is seeing rapid urbanization also because of the push from the rural areas where drought and low farm productivity are driving migrants to cities. The concentration of economic development in a few cities and particularly the largest implies a population boom in very short periods of time that in turn severely tests the coping capacity of city governments. One of the most visible outcomes of the rapid urbanization has thus been the persistence and formation of slums.

\section{URBAN SLUM FORMATION}

One billion people or one third of the world's population is estimated to be living in either slum or squatter settlements. ${ }^{4}$ The largest proportion of population living in slums in the world is in the Asian region, which is also urbanizing at the fastest rate. In 2001, Asia had 554 million slum dwellers, or $60 \%$ of the world's total. In South Asia, slum and squatter settlement population constituted $58 \%$ of total urban population compared to $36.4 \%$ in East Asia and $28 \%$ in Southeast Asia. ${ }^{5}$ The estimates of population in slums in Table 4 show that the proportion of slum population in cities is generally higher than that of the world as a whole. In Southeast Asia, where urban population is $38.3 \%$ of the total population, $28 \%$ of this urban population is living in slums (see Table 4).

TABLE 3 GDP of urban areas compared with national GDP

\begin{tabular}{lcccc}
\hline City & $\begin{array}{c}\text { National } \\
\text { GDP per } \\
\text { capita (US\$) }\end{array}$ & $\begin{array}{c}\text { City GDP } \\
\text { per capita } \\
\text { (US\$) }\end{array}$ & $\begin{array}{c}\text { City GDP/ } \\
\text { capita/national } \\
\text { GDP/capita }\end{array}$ & $\begin{array}{c}\text { City GDP } \\
\text { (US\$ billion) }\end{array}$ \\
\hline Tokyo & 25,430 & 35,600 & 1.40 & 890.1 \\
Osaka & 25,430 & 32,300 & 1.27 & 339.1 \\
Seoul & 5,400 & 6,080 & 1.13 & 66.9 \\
Bangkok & 1,420 & 4,900 & 3.45 & 34.8 \\
Shanghai & 370 & 1,350 & 3.66 & 18.0 \\
Manila & 730 & 1,400 & 1.92 & 11.3 \\
Jakarta & 570 & 1,230 & 2.15 & 9.4 \\
Calcutta & 350 & 875 & 2.50 & \\
\hline
\end{tabular}

Source: Prud'homme (1996) p. 101-103 
TABLE 4 Population living in slums (UN-HABITAT, 2001 estimates)

\begin{tabular}{lcccc}
\hline & $\begin{array}{c}\text { Total urban } \\
\text { population } \\
\text { (millions) }\end{array}$ & $\begin{array}{c}\text { Urban population } \\
\text { as \% of total } \\
\text { population }\end{array}$ & $\begin{array}{c}\text { Urban slum } \\
\text { population } \\
\text { (millions) }\end{array}$ & $\begin{array}{c}\text { Slum population as } \\
\% \text { of total urban } \\
\text { population }\end{array}$ \\
\hline World & 2,923 & 47.7 & 924 & 31.6 \\
Developed regions & 902 & 75.5 & 54 & 6.0 \\
Europe & 534 & 73.6 & 33 & 6.2 \\
Others & 367 & 78.6 & 21 & 5.7 \\
Developing regions & 2,022 & 40.9 & 870 & 43.0 \\
Eastern Asia & 533 & 39.1 & 194 & 36.4 \\
Eastern Asia excluding & 61 & 77.1 & 16 & 25.4 \\
$\quad$ China & & & 262 & 58.0 \\
South Central Asia & 452 & 30.0 & 57 & 28.0 \\
South Eastern Asia & 203 & 38.3 & 41 & 33.1 \\
Western Asia & 125 & 64.9 & & \\
\hline
\end{tabular}

Source: UN-HABITAT, Global Urban Observatory, 2003. Estimations based on Total and Urban population: UN Population Division, World Urbanization Prospects: The 2001 Revision

Rapid urban population growth has outpaced the ability of city authorities to provide for housing and environmental and health infrastructure. This is evident in the proportion of the population that is living in slums as illustrated in Table 5. Cities such as Dhaka in Bangladesh or Mumbai in India are, realistically speaking, metropolitan or urban regions, spanning large territorial areas. Others like Metro Manila in the Philippines or Jakarta in Indonesia are really megaurban regions. The nature of the governments differs considerably. Jakarta's urban government has the status of a provincial government equal to that of other provinces in Indonesia. The metropolitan government in Manila coordinates among some 17 local authorities, the majority of which are municipalities with a few town councils.

Squatter and slum settlements have formed mainly because of the inability of city governments to plan and provide affordable housing for the low-income segments of the urban population. Hence, squatter and slum housing is the housing solution for this low-income urban population. In the megaurban regions or metropolitan areas, part of the problem would lie in the coordination among different authorities that are in charge of economic development, urban planning, and land allocation. Such coordination issues also exist between the city and national governments.

TABLE 5 Urban population living in squatter and slum settlements, 1980s

\begin{tabular}{lr}
\hline Country & Percent \\
\hline Indonesia & 54 \\
Bangladesh & 47 \\
India & 36 \\
Philippines & 28 \\
Sri Lanka & 21 \\
Thailand & 16 \\
Malaysia & 15 \\
Republic of Korea & 1 \\
\hline
\end{tabular}


The economically more dynamic regions such as Asia have experienced strong growth because the state sector drives development agendas. National and city governments have generally adopted the position that economic development will take care of basic needs such as housing and environmental and health infrastructure. In cities of higher income countries such as Malaysia, private sector developers are more interested in building homes for the middle-income market. The proliferation of slum and squatter settlements shows, however, that planned economic growth has to be aligned with the planned development of health services, environmental infrastructure, and housing.

For the scale and speed of urbanization that has been taking place in developing countries of Asia, most municipal governments are unequipped physically, fiscally, politically, and administratively to tackle the problems of providing the basic infrastructure services to their people. In a situation of scarce resource allocation, the urban poor are frequently badly placed to compete for essential services. Biases in investment standards, pricing policy, and administrative procedures, more often than not, skew services in favor of the rich, denying the poor shelter, safe water, acceptable sanitation, minimal nutrition, and basic education. $^{6}$

In Ho Chi Minh City in Vietnam, neither the government nor the private developers are able to provide the housing needed for 50,000 migrants per year. An additional 20,000 young urban households are formed annually who enter the real estate market. ${ }^{7}$ The resulting growth in squatter and slum settlements now comprises $15 \%$ of housing in the city. This kind of housing is associated with lack of sanitation and also air pollution. ${ }^{8}$ In other lower-income cities like Dhaka, only one quarter of the population in the city is connected to the piped sewerage system with two in three among households served with potable water supply. ${ }^{9}$ The outcome has been one of the highest rates of death from infectious diseases among Asian cities. Low-income cities in South Asia and Africa are more vulnerable to environmental disasters such as floods and, hence, disease because of their fragile social infrastructure. The City Development Index computed by the United Nations Centre for Human Settlements, Global Urban Indicators and Habitat II, showed cities in poorer countries-Phnom Penh in Cambodia, Vientiane in Laos, and Hanoi in Vietnam-lagging behind Seoul, Hong Kong, and Singapore with regard to water connections, sewerage, life expectancy, child mortality, wastewater treatment, and solid waste management.

In many cities, such as in Metro Manila in the Philippines and in Kuala Lumpur in Malaysia, rapid development of new real estate comprising condominiums and shopping malls has led to "...gridlocked traffic conditions, severe environmental conditions (air, noise, and river pollution), unstable squatter tenements sandwiched between prime commercial complexes and high class condominiums, loss of heritage edifices, and neglect of human development." ${ }^{10}$ With the intensely competitive demand for land in cities, the urban poor will increasingly be marginalized. Many are now settling at the fringes of the most rapidly growing cities. Rapid growth of the larger cities and megaurban regions in the developing countries is reflected in their being surrounded by dense and generally impoverished shantytowns and numerous other forms of so-called informal and/or irregular housing. These are characterized by inadequate infrastructure, service provision, and security of shelter and land tenure. ${ }^{11}$ In these "periurban" zones or areas of 
rural-urban interface, there are usually far from clear administrative responsibilities between the urban and rural governments or provincial and national levels of governance. $^{12}$

\section{LINKING ECONOMIC DEVELOPMENT AND URBAN GROWTH TO HOUSING: CASE STUDY IN SINGAPORE}

Singapore's highly successful public housing program, which provides homes for $85 \%$ of the population, has been an important aspect of its planned urbanization strategy for economic development. This development agenda necessitated the redevelopment of the central area where in the 1960s some two thirds of the population were concentrated. The housing conditions then were the same as those in today's poor urban neighborhoods. ${ }^{13}$

In Singapore, 130,000 people live in squalid and insanitary attap kampungs throughout the municipal areas. They have standpipe water and the most primitive sanitation. "It is a physical impossibility to eject these people; they have nowhere else to go. Although the municipality does excellent work in trying to keep these areas properly drained and free from disease, nevertheless they constitute a menace to the general health of the whole city." ${ }^{14}$ Singapore squatters demand fantastic prices for possession; a parcel of land free from squatters is three times as expensive as land that is squatter-occupied.

Health problems experienced by slum residents included worms in children. Water-borne illnesses, cholera and dysentery, were a perennial problem, largely because of the lack of adequate potable water supply. Other common illnesses because of congested living conditions and low standards of hygiene included tuberculosis.

Public housing estates were first developed in and around the fringes of the central area. These not only reduced the dislocation of the households being resettled but also obviated the necessity for the public housing authority to provide an exhaustive list of estate facilities to meet everyday needs of the people being resettled. Many resettlement programs have failed because of the virtual banishment of the low-income households to distant locations often outside of the city altogether.

Only incrementally did the public housing authority develop housing estates and new towns further away from the city center. The first new town developed was located some 6 to $8 \mathrm{~km}$ away. To compensate for the longer distance between their new homes and the city center, this new town was planned with a full range of

TABLE 6 Housing trends among public housing residents in Singapore

\begin{tabular}{lcrr}
\hline & \multicolumn{3}{c}{ Year } \\
\cline { 2 - 4 } Apartment types & $1985, \%$ & $1990, \%$ & $2000, \%$ \\
\hline 1- and 2-room & 19.4 & 8.2 & 5.0 \\
3-room & 47.5 & 35.4 & 25.7 \\
4-room & 24.0 & 27.4 & 33.2 \\
5-room, executive, maisonette, and larger units & 9.0 & 13.0 & 23.7 \\
\hline
\end{tabular}

Source: Singapore Census of Population (2000) p. 6; Wong and Yeh (1985) p. 377 
neighborhood facilities and services, including public bus transport. Furthermore, the new town was located along highways connecting the town center to the city, thus facilitating relatively convenient and fast transportation to workplaces.

In the late 1960s a financing scheme was introduced to enable households to buy public housing units through the use of a part of the money in their retirement savings fund-Central Provident Fund. The copayment scheme between state and homebuyers ensured financing for the housing program. In the beginning, the homes built were small. The general expectation was that families would move to bigger apartment units once their incomes improved either from wage increases or when the children grew up and were able to complement their parents' incomes. So as illustrated in Table 6, the proportion of residents living in smaller one- and two-room apartments declined to $5 \%$ in 2000 whereas that living in the larger four- and fiveroom apartments has increased to more than half among public housing residents.

Public housing apartments have been allocated to applicants on a first come, first served basis. Furthermore, public housing estates in Singapore have been equitably developed throughout the city-state providing locational choices. For the urban poor, transport, apart from housing, usually constitutes the major household expense item.

All the public housing estates are connected to modern sanitation and sewerage treatment works. In addition, there is piped potable water supply and electricity. A solid waste management system was also provided and put in place. Hence, the public housing program was effective in breaking the vicious cycle of the lack of provision of environmental and health infrastructure, which has led to highly unhealthy and socially vulnerable conditions in slum and squatter settlements.

The discussion of the success that cities such as Singapore and Hong Kong have seen in addressing slum formation underscores the importance of urban housing provision with planned economic development and projected urban growth. In the case of the cities with relatively high proportions of urban population living in slums, such as Jakarta or Metro Manila, linkages do not exist between economic development or urban growth and the provision of housing. So there is economic growth in these cities that governments have not effectively linked to the urban growth expected and the need to provide for urban housing. The implications, as discussed above, have been the persistence and proliferation of slums. Low-income segments of the urban population are unlikely to afford the increasing costs of housing in rapidly growing cities unless there is a provision for such affordable housing by the city government, given the economic growth that is being planned.

\section{FURTHER READING}

Bradford A, Brook R, Hunshal CS. Wastewater irrigation in Hubli-Darwad, India: Implications for health and livelihoods. Environ Urban. 2003;15:157-170.

ESCAP (Economic and Social Commission for Asia and the Pacific). State of Urbanisation in Asia and the Pacific 1993, ST/ESCAP/1300. ESCAP; 1993.

Lo F-C, Yeung Y-M, eds. Emerging World Cities in Pacific Asia. Tokyo: United Nations University; 1996.

Prud'homme R. Management of megacities: Institutional dimensions. In: Stubbs J, Clarke G, eds. Megacity Management in the Asian and Pacific Region: Policy Issues and Innovative Approaches, Proceedings of the Asian Development Bank and the World Bank Regional Seminar on Megacities Management in Asia 
and the Pacific, 24-30 October 1995, Vol. 1. Manila: Asian Development Bank; 1996:99-132.

Singapore Department of Statistics. Households and Housing. Singapore

Census of Population 2000, Advance Data Release No. 6; 2001.

United Nations. World Urbanisation Prospects: The 1999 Revision, Data

Tables and Highlights. New York: United Nations Population Division, United Nations, ESA/P/WP.161; 2000.

Wong AK, Yeh SHK, eds. Housing a Nation-25 Years of Public Housing in Singapore. Singapore: Maruzen Asia; 1985.

\section{REFERENCES}

1. Hardoy J, Satterthwaite D. Squatter Citizen-Life in the Urban Third World. London: Earthscan; 1995:301.

2. Population Reference Bureau. Human Population: Fundamentals of Growth Patterns of World Urbanisation. USA: Population Reference Bureau. Available at: http:// www.prb.org. Accessed on: 15 Dec 2004.

3. Laquian AA. Beyond Metropolis-The Planning and Governance of Asia's Mega-Urban Regions. Baltimore: The Johns Hopkins University Press; 2005.

4. UNDP. UN Millennium Project-Investing in Development: A Practical Plan to Achieve the Millennium Development Goals. London: Earthscan; 2005.

5. UNFPA. State of the World Population. New York: UNFPA; 2004.

6. Yeung Y-M. The Urban Poor and Urban Basic Infrastructure Services in Asia: Past Approaches and Emerging Challenges' Occasional Paper No. 7, Hong Kong Institute of Asia-Pacific Studies. Hong Kong: The Chinese University of Hong Kong; 1991:7.

7. Marr RL. Hanoi and Ho Chi Minh City: the long struggle of two cities/recovering from endless war. In: Schneider-Silwa R, ed. Cities in Transition-Globalisation, Political Change and Urban Development. Dordrecht: Springer; 2005:273-320, 305.

8. World Bank. World Development Report. Washington, DC: World Bank; 2004:14.

9. McGee TG. Urbanisation Takes on New Dimensions in Asia's Population Giants. USA: Population Reference Bureau. Available at: http://www.prb.org. Accessed on: August 2005.

10. Lee BT. Urban Development in Malaysia: The Case for a More Holistic and Strategic Approach to Urbanisation. In: Knie C, ed. Urban and Peri-urban Developments-Structures, Processes and Solutions. Cologne: University of Cologne; 2006:1-14.

11. MacGregor D, Simon D, Thompson D. The Peri-urban Interface-Approaches to Sustainable Natural and Human Resource Use. London: Earthscan; 2006:7.

12. Sutandyo-Buchholz A. How Essential is Community-based Solid Waste Management in Peri-urban Areas? Case-study of Jakarta, Indonesia. In: Knie C, ed. Urban and PeriUrban Developments-Structures, Processes and Solutions. Cologne: University of Cologne; 2006:95-104.

13. Abrams C. Squatting and squatters. In: Abu-Lughod J, Hay R Jr, eds. Third World Urbanisation. London: Methuen; 1977:298.

14. Fraser JM. Housing and planning in Singapore. Town Plan Rev. 1952;23:5-25. 